\title{
Astronomy and landscape in Ancient Egypt: Challenging the enigma of the minor step pyramids
}

\author{
Juan Antonio BELMONTE \\ Mosalam SHALTOUT \\ Magdi FEKRI
}

\begin{abstract}
The minor step pyramids (MSPs) form a coherent group of seven monuments distributed along Egyptian geography with a series of common characteristics that make them unique and distinct from other buildings of similar typology. The purpose of these pyramids is a matter of dispute among Egyptologists and most proposals could be interpreted as sad examples of vox nihil. By contrast, our archaeoastronomical study of the monuments would suggest that minor step pyramids were built at certain locations and with particular orientations that might relate them to the preliminary stages and consolidation, during the reign of king Snefru, of two master creations of early dynastic Egypt, the civil calendar and the stellar Afterlife later appearing in the Pyramid Texts.

Las pequeñas pirámides escalonadas integran un grupo coherente de siete monumentos distribuidos a lo largo de la geografía egipcia con una serie de características comunes que las diferencian y las singularizan con respecto a otros edificios de similar tipología. El propósito de estas pirámides constituye un debate abierto entre los egiptólogos, si bien la mayoría de las propuestas para explicar su causa son tristes ejemplos de explicaciones ad hoc sin gran fundamento. Por el contrario, nuestro estudio arqueoastronómico de los monumentos sugeriría que las pequeñas pirámides escalonadas fueron construidas en ciertas localizaciones, y con orientaciones peculiares, que podrian relacionarlas con los primeros estadios y el proceso de consolidación, durante el reinado de Snefru, de dos creaciones maestras del periodo dinástico temprano de Egipto, el calendario civil y la escatología estelar, presente en los Textos de las pirámides.
\end{abstract}

Key Words: Old Kingdom, Huni, Snefru, minor step pyramids, astronomy, Pyramid Texts

$\mathrm{M}$ inor step pyramids (hereafter MSPs) have been an archaeological enigma since they were revealed to the scientific community in the $18^{\text {th }}$ Century ${ }^{1}$, and especially after they were identified as a coherent group by the seminal work of Günter
Dreyer and Werner Kaiser ${ }^{2}$. As Mark Lehner recently argued, the purpose of these small pyramids is a mystery ${ }^{3}$, with almost as many hypotheses to explain them as there are researchers who have dealt with the problem.

* We wish to express our acknowledgement to our colleague Dr. Zahi Hawass for his strong support of the Archaeoastronomy Mission as Director of the Supreme Council of Antiquities. We also express our gratitude to the various inspectors, guides and escorts who join us during the fieldwork; they were very kind and helpful. The first author is indebted to the Egyptologist R. Krauss for many valuable discussions and for his authorization to discuss in this paper some of his material prior to publication. Corrections, comments and suggestions from the Egyptologists L. Gabolde and J. Lull and the archaeoastronomers C. González and E. Krupp greatly enriched the paper. Finally, the editors of the journal, notably the Egyptologist M. A. Molinero Polo, also proposed fundamental emendations. This work is partially financed under the framework of the projects P310793 "Arqueoastronomía" of the Instituto de Astrofisica de Canarias, and AYA2004-01010 "Orientatio ad Sidera” of the Spanish Ministry of Education and Science.

1. See, e.g., Denon, 1802.

2. Dreyer / Kaiser, 1980.

3. Lehner, 1997: 96. 


\section{InSCRUTABLE MONuments}

MSPs are seven buildings scattered from south to north along the Nile (Figure 1):

(1) on the island of Elephantine;

(2) near Naga el Ghoneimiya, to the south of Edfu;

(3) at El Kula, a short distance north of Kom el Ahmar;

(4) close to Naqada, near Nubt, the ancient city of the god Seth;

(5) at Sinki, a few kilometres south of Abydos;

(6) at the cemetery associated with the Zawiyet el Mayitin, $10 \mathrm{~km}$ south of Minya and the only one on the east bank of the river; and

(7) at Seila, in the heights of Gebel el-Rus, a low chain of hills separating the Oasis of Fayum and the desert landscapes descending to the Nile valley.

As shown in Figure 2, El Kula is the best preserved of the monuments and exhibits most of their common characteristics: small stones of some $60 \times 100 \mathrm{~cm}$, square base of some 35 cubits (Seila is larger), three steps (except for Zawiyet el Mayitin, which could have had four, or Seila that certainly had four) and the absence of any associated chamber that could help to identify them as tombs or cenotaphs. However, they differ in their orientation, the very essence of our question.

Three of them have been excavated and partially restored, Elephantine, Sinki and Seila ${ }^{4}$. El Ghoneimiya and Naqada are little more than a hill of pebbles and sand but still a few

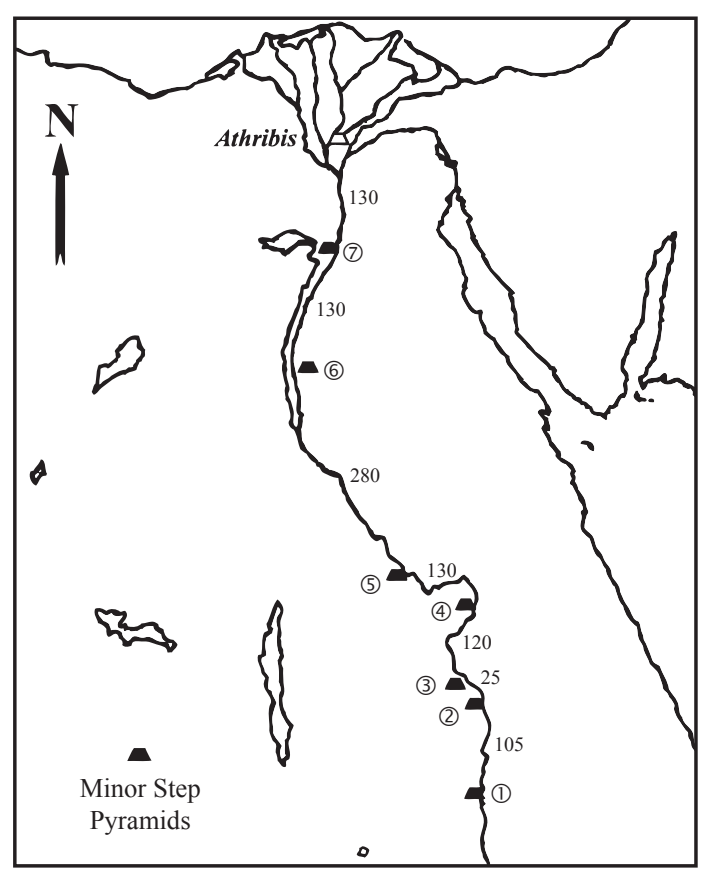

Figure 1. Map of Egypt showing the location of the seven MSPs along the course of the Nile, with the approximate distance between them in $\mathrm{km}$ (nearest point to the river for Seila). The location of the now lost Athribis pyramid is also marked.

layers are visible. The excavations at Seila identified a chapel on the eastern side of the MSP where a few important discoveries pointed towards King Snefru (ca. 2570 B.C.E. $)^{5}$ as the most probable builder of this particular monument. However, the excavations at Elephantine discovered what has been interpreted as an administrative building of the $3^{\text {rd }}$ Dynasty; within that context, the archaeologists found a stone cone with the name of King Huni written on its base in a cartouche ${ }^{6}$. This finding has been related to the MSP on site and consequently the pyramid has been tentatively assigned to the reign of Huni. The small

4. For Elephantine, see Kaiser et alii, 1980: 276-80; for Sinki, see Dreyer / Swelim, 1982; for Seila, see Swelim, 1987.

5. 2570 B.C.E. is a date close to the ascension of Snefru according to Hornung / Krauss / Warburton, 2006: 490, who proposed the periods 2568-2535 to 2543-2510 B.C.E. (earliest ascension date at 2578 B.C.E.) for his reign. Other dates are 2613-2589 B.C.E. according to Shaw, 2000:482; 2520-2470 B.C.E. according to Dodson / Hilton, 2004: 288; or 2639-2604 to 2589-2554 B.C.E. according to von Beckerath, 1997: 187.

6. Dreyer / Kaiser, 1980: P1. 71. 
differences between Elephantine and the other MSPs inclined several scholars, including some of the excavators of the monuments, to accept an earlier construction by Huni of most MSPs except Seila, which would have been constructed by Snefru in the early stages of his reign. However, Andrzej Ćwiek ${ }^{7}$, in a most enlightening paper on the topic, has com-

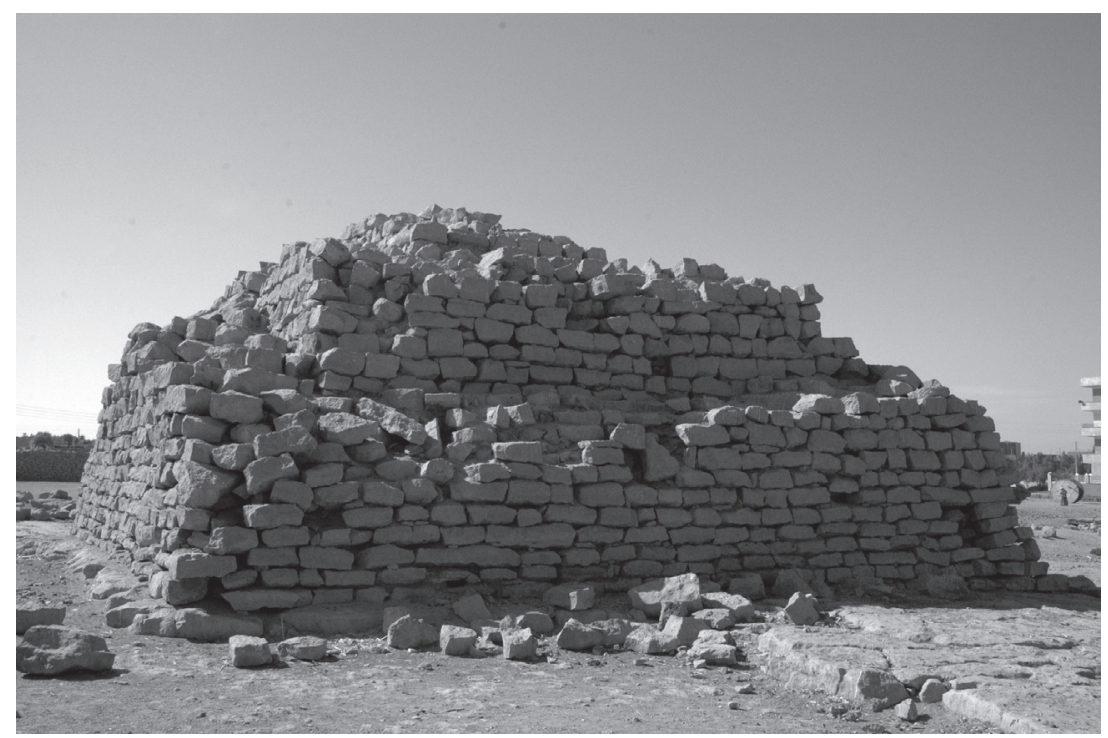

Figure 2. The three-step pyramid of El Kula, the best preserved of all MSPs. pletely rejected that idea and has assigned all MSPs to the reign of Snefru. Aidan Dodson is of the same opinion $^{8}$. The excavations at Sinki revealed a fascinating aspect of the architecture of MSPs, since the mud-brick construction ramps were found still in situ (Figure 3), indicating that this particular pyramid was left unfinished at its second step, while most of the other MSPs (certainly Seila and El Kula) were finished or almost completed.

The purpose of these building is still an enigma that has generated explanations ranging from the bizarre fantasies of the lunatic fringe $^{9}$ to serious speculations that would make MSPs cenotaphs for the $k a$ of royal wives in their homelands, archaic benbens, i.e. the predecessor of $5^{\text {th }}$ Dynasty solar temples $^{10}$, or local symbols of royal power in important cities of the country ${ }^{11}$. We have not mentioned so far that MSPs were located at

or near the site of some of the most important capitals of the ancient provinces of Upper Egypt during the Old Kingdom: Abu (Elephantine), Behedet (Edfu), Nekhen (El Kula), Nubt (Naqada) and This-Abydos (Sinki). Zawiyet el Mayitin was also located at ancient Hebenu. Only Seila breaks this rule, being located within a bird's-eye view of Meidum, where Snefru was building his first tomb in the form of a huge step pyramid. Ćwiek has analysed the majority of these proposals, rejecting most of them or re-interpreting the symbolic aspect, proposing from a firm basis of evidence that MSPs might be a sort of local sanctuaries built under Snefru for the royal cult ${ }^{12}$; an effort that would eventually be abandoned (hence the unfinished character of Sinki) once most of the energies of Old Kingdom Egyptian society were diverted to the construction of huge pyramids by Snefru himself and his successors.

7. Ćwiek, 1998.

8. Dodson, 2003.

9. Simply type "Small Step Pyramids" or "Minor Step Pyramids" at any of the Internet search engines.

10. As suggested by Dreyer / Swelim, 1982.

11. Lehner, 1997.

12. Ćwiek, 1998. 


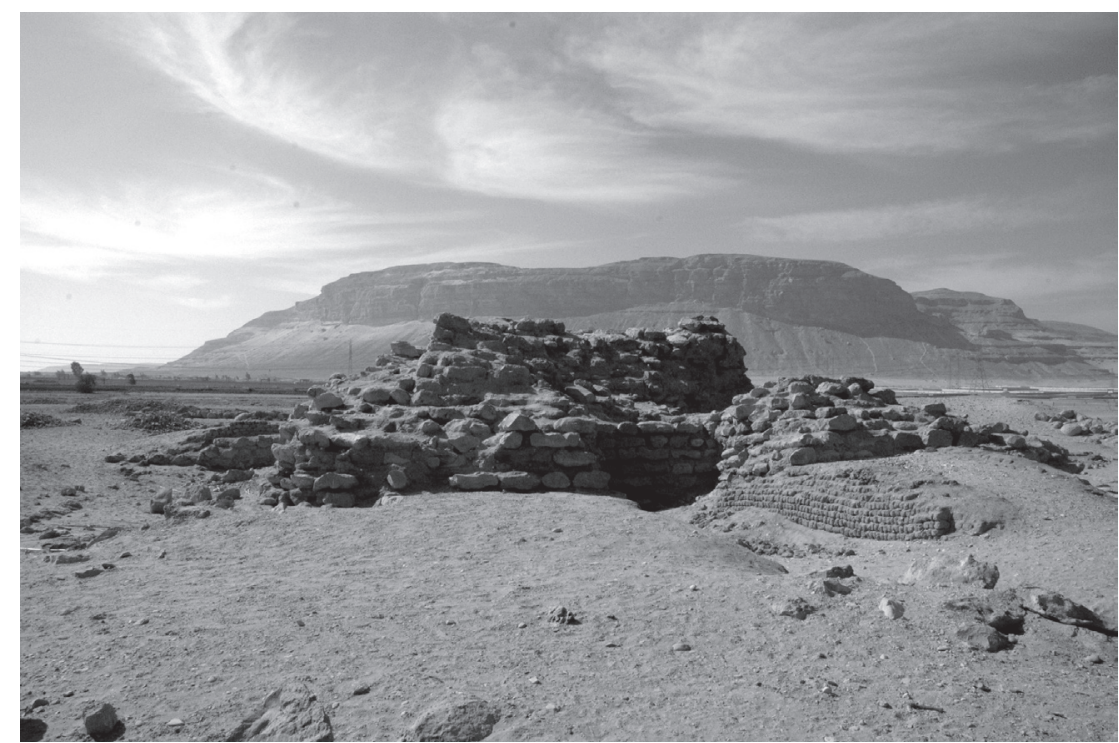

Figure 3. The pyramid of Sinki, near Abydos. This monument was left unfinished. Notice the mud-brick construction ramps still attached to the sides of the pyramid.

An alternative explanation, relating to the geographical location of MSPs, has been proposed by Rolf Krauss ${ }^{13}$ which has to do with the distance between consecutive MSPs (Figure 1). An additional monument at Athribis, identified only by ancient reports ${ }^{14}$, has sometimes been included within the group although its inclusion is questionable ${ }^{15}$. Krauss noticed that with one exception, the small pyramids are situated at distances of about $150 \mathrm{~km}$. along the Nile, i.e. the distance which is covered in one day by the Nile flooding when it flows at a velocity of about $6 \mathrm{~km}$. per hour. Accordingly, he suggests the idea that the small pyramids

[10] could mark the progress of the high flood in full-day intervals, beginning at Elephantine. Actually, the distance is a little shorter (close to 12 Iteru or $126 \mathrm{~km})^{16}$ and there are exceptions to the rule, such as the case of El Ghoneimiya, or problems such as the distance between Seila and the river (more than $10 \mathrm{~km}$ ) or the non-existence of certain monuments which, however, could have stood near Asyut, another important provincial capital. At least from our point of view, the hypothesis may sound reasonable for MSPs (1), (3), (4) and (5) and could be linked to the ideas we shall now analyse and discuss.

\section{Orientating Minor Step Pyramids}

For the last few years, the authors have been involved in the Egyptian-Spanish Mission for the Archaeoastronomy of ancient Egypt, one of whose objectives is to measure the orientation of as many ancient monuments as possible. We have already obtained substantial results concerning the temples that have convinced us that ancient Egyptian shrines were orientated according to local landscape, understanding landscape in its broadest meaning, including both the terrestrial (topographic) and celestial (astronomical) aspects ${ }^{17}$.

13. R. Krauss (private communication, 2005). We had a productive interchange of ideas on the topic when preparing Paper 2, cf. infra, n. 17.

14. Description de l'Egypte, Vol. V, Pl. 27. This pyramid is now lost due to the wild urban expansion of the city of Benha. It is marked by an empty symbol in Fig. 1 .

15. Ćwiek, 1998.

16. The Iteru was the larger unity of length of ancient Egyptian $(10.5 \mathrm{~km})$, consisting of 20,000 royal cubits. The number 12 has strong calendrical meanings.

17. Four papers have been produced so far: Shaltout / Belmonte, 2005; hereafter "Paper 1". Belmonte / Shaltout, 2006;.../... 


\begin{tabular}{|c|c|c|c|c|c|c|c|c|c|c|}
\hline Pyramid & $\mathrm{L}(\%)$ & $1(\% /)$ & $\mathrm{a}_{\mathrm{N}}\left({ }^{\circ}\right)$ & $\mathrm{h}_{\mathrm{N}}\left({ }^{\circ}\right)$ & $\delta_{\mathrm{N}}\left({ }^{\circ}\right)$ & $\Delta\left(^{\circ}\right)$ & $\mathrm{a}_{*}\left({ }^{\circ}\right)$ & $\mathrm{h}_{*}\left({ }^{\circ}\right)$ & $\delta_{*}\left({ }^{\circ}\right)$ & Comments \\
\hline Elephantine & $24 / 06$ & $32 / 54$ & 343 & 0 & $601 / 2$ & 46 & 73 & 2 & $16^{1 / 4}$ & 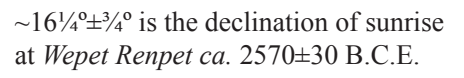 \\
\hline $\begin{array}{l}\text { Ghoneimiya } \\
\text { (South Edfu) }\end{array}$ & $24 / 56$ & $32 / 50$ & $31 / 2$ & 2 & $661 / 2$ & $12^{1 / 2}$ & & & & $\begin{array}{l}\text { Lower culmination at the horizon of } \\
\text { Merak } c .2570 \text { B.C.E. } \\
\text { Lowest latitude in Egypt where } \\
\text { Meskhetyu is circumpolar }\end{array}$ \\
\hline El Kula & $25 / 08$ & $32 / 44$ & $316^{1 / 4}$ & 0 & $401 / 2$ & $-8^{1 / 4}$ & $1 \frac{1 / 4}{4}$ & $2 *$ & $66^{3 / 4}$ & $\begin{array}{l}\text { Similar to the upper case; but with } \\
\text { quarter-cardinal orientation }\end{array}$ \\
\hline Naqada & $25 / 58$ & $32 / 44$ & $241 / 2$ & $01 / 2$ & 55 & $14^{1 / 2}$ & $114 \frac{1}{2}$ & $\begin{array}{c}0 \\
2^{*}\end{array}$ & $\begin{array}{l}-22^{1 / 4} 4 \\
-21^{1 / 4}\end{array}$ & 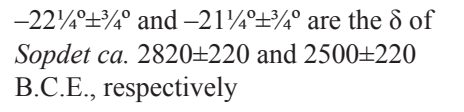 \\
\hline Sinki & $26 / 09$ & $31 / 58$ & $318^{3 / 4}$ & 0 & 42 & $-83 / 4$ & $33 / 4$ & 0 & 63 & $\begin{array}{l}\text { Similarly orientated as El Kula. Early } \\
\text { member of the quarter-cardinal family }\end{array}$ \\
\hline $\begin{array}{l}\text { Zawiyet el } \\
\text { Mayitin }\end{array}$ & $28 / 03$ & $30 / 50$ & $331 \frac{3 / 4}{4}$ & $0 \mathrm{~B}$ & $501 / 2$ & $-4^{3 / 4}$ & $241^{3 / 4}$ & $0^{1 / 2}$ & $-243 / 4$ & $\begin{array}{l}\text { Winter solstice sunset? Lowest latitude } \\
\text { in Egypt where UMi (the Small Adze?) } \\
\text { is circumpolar } c a .2570 \text { B.C.E. }\end{array}$ \\
\hline Seila & $29 / 23$ & $31 / 03$ & 0 & 0 & 60 & -2 & & & & $\begin{array}{l}\text { One of the first buildings with cardinal } \\
\text { orientation. } 1 \text { st use for a pyramid of the } \\
\text { simultaneous meridian transit of Phecda } \\
\text { and Megrez } \mathrm{ca} .2570 \text { B.C.E. }\end{array}$ \\
\hline
\end{tabular}

Table 1: Orientation data on the seven minor step pyramids in Egypt.

After the name, latitude $(\mathrm{L})$ and longitude $(\mathrm{l})$ are presented, followed by azimuth $\left(\mathrm{a}_{\mathrm{N}}\right)$, angular height $\left(\mathrm{h}_{\mathrm{N}}\right)$ and the corresponding declination $\left(\delta_{\mathrm{N}}\right)$ for the pyramid face closest to north (as in Figure 4 ), angular distance from due-north for the course of the Nile on site $(\Delta)$, and some additional orientating data (as presented in Figure 4). The last column presents a sketch of the corresponding archaeoastronomical interpretation, as discussed in the text. The asterisks stand for special values of $\mathrm{h}$.

Of course MSPs were part of our interests since we were most intrigued by their enigmatic character and we wanted to check if archaeoastronomy could help to challenge the mystery. Our data are presented in Table 1. In our first campaign, we measured Elephantine and our data agreed with previous reports. Zawiyet el Mayitin was measured in the second campaign with slightly different results. However, it was in our $3^{\text {rd }}$ cam- paign at Seila when we were astonished by an almost perfect cardinal orientation, whilst previous findings offered a completely wrong value of $12^{\circ} \mathrm{NW}^{18}$. This demonstrated the necessity for accurate local measurements of most of ancient Egyptian monuments, which was the central idea in the creation of our project. Finally, the remaining monuments were measured in December 2006, our last $\left(5^{\text {th }}\right)$ campaign so far.

hereafter "Paper 2". Shaltout / Belmonte / Fekri, 2007; hereafter "Paper 3 (Part I)". Shaltout / Belmonte / Fekri, 2007; hereafter "Paper 3 (Part II)". And Belmonte / Shaltout / Fekri, in press; hereafter "Paper 4".

18. See, for example, Dreyer / Kaiser, 1980, and Lehner, 1997. 


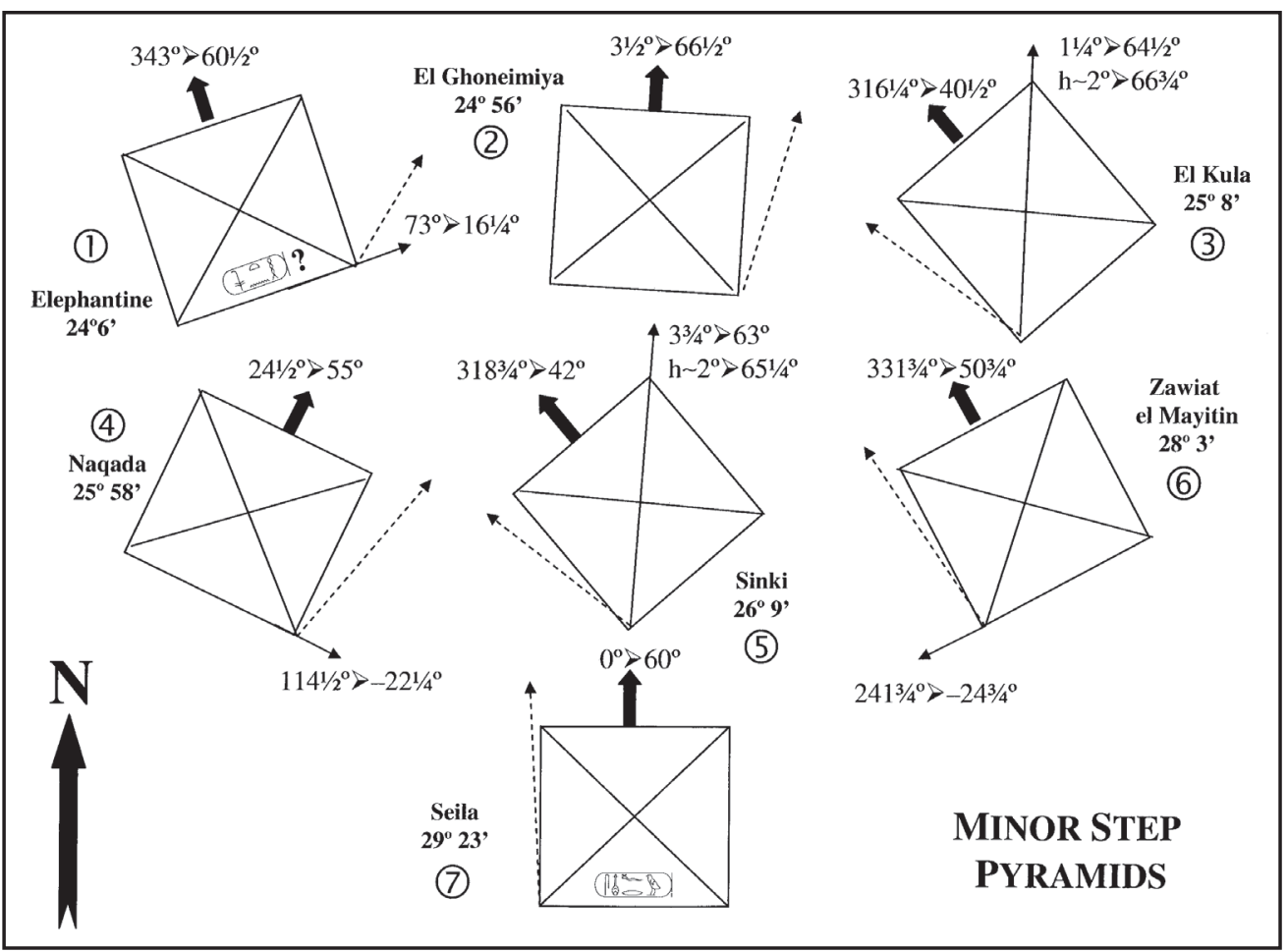

Figure 4. Schematic diagram of the orientation of the seven MSPs, numbered from south to north. For each of the seven monuments, the image shows the name and latitude, its closest orientation (azimuth) towards north and the corresponding declination (thick black arrow), the approximate flow of the Nile on site (dot-line arrow) and the azimuth and declination of some additional important astronomical orientations as discussed in the text (thin arrow). The pyramid of Seila was almost certainly built by Snefru while that at Elephantine has been assigned on slender evidence to his predecessor, Huni

We want to emphasise that in our project we were not seeking extreme-precision alignments. Bearing this in mind, and considering the rough state of preservation of MSPs (with the possible exception of El Kula), we obtained our measurements using high precision [12] compasses, correcting for local magnetic declination $^{19}$, and clinometers. These instruments permit a theoretical $1 / 4^{\circ}$ precision for both kinds of measurements. However, owing to various considerations, an error of at least $12^{\circ}$ in both azimuth and angular height is probably nearer to reality. As the first author has dis- cussed elsewhere ${ }^{20}$, we can affirm without fear of being grossly in error that, for the latitudes of Egypt, a precision of $1 / 2^{\circ}$ is perhaps the best we can expect in solar or very bright star observations near the horizon and, in the case of fainter stars, the errors in estimating the azimuth can range from that value to several degrees. According to our own experience, we consider our data to be of good enough quality to pursue the study of the orientation of MSPs.

Figure 4 is a schematic diagram of the orientation of MSPs, complementary to Table 1.

19. Magnetic alterations are not expected in Egypt, where most of the terrain is limestone and sandstone. In any case, the MSPs were mostly measured along their four faces, and from both sides, checking for possible alterations. Our own experience after four years of extensive fieldwork and cross-checking of previous data supports this idea.

20. Belmonte, 2006. 
The first topic we can analyse is the Nile hypothesis, as discussed in our earlier studies (Papers 1 to 4). With the exception of Elephantine, the other six monuments have a side almost parallel to the river. Actually, the average value of the difference $(\Delta)$ for these six pyramids is $\sim 1 / 2^{0} \pm 11^{\mathrm{o}}$. Hence, our immediate conclusion would be that MSPs are orientated according to the course of the Nile. However, our experience has shown that the answer is not always so simple. It is precisely the exception to the rule, Elephantine, which offered the first challenge, by giving an alternative astronomical theory. The perpendicular axis of the pyramid (see Figure 4 and Table 1) is orientated to a declination $\sim 16^{1} \%^{\circ}$ that corresponds to sunrise at Wepet Renpet (Egyptian New Year's Eve) $c a .2570$ B.C.E., with an interval of \pm 30 years due to our estimated error of $34^{\circ}$ for the declination. The first author has proposed in a previous paper in this journal that solar observations at the summer solstice at Elephantine might have permitted the establishment of the duration of the year at $\sim 365$ days a century or so earlier ${ }^{21}$. Now, at the beginning of the reign of Snefru, the wandering character of the Egyptian civil calendar had moved the beginning of the year to a different date and the king might have decided to build a monument to commemorate this fact that perhaps could serve as a new tool (a gnomon?) with unique astronomical characteristics ${ }^{22}$ to check the actual duration of the civil year, similar to other monuments of the king and his direct successors. Fascinated by this possibility, we have analysed the possible astronomical connotations of the other pyramids with promising results that in no way abandon the Nile hypothesis. MSPs can be divided in two groups according to their orientation (Figure 4). One group is that formed by those monuments with cardinal or quarter-cardinal orientations, as defined in Paper 3 and verified in Paper 4, El Ghoneimiya, El Kula, Sinki and Seila. In this case, a close N-S direction was first established that will be the axis of symmetry of the pyramid (cardinal) or this will be obtained by rotating the axis by $45^{\circ}$ (quarter-cardinal). Another group is formed by Elephantine, Naqada and Zawiyet el Mayitin where the orientation is far from this simple rule. We will discuss this group first.

After Elephantine (already discussed), Naqada offers another curious alternative (Table 1). Here, the perpendicular direction would be that of the rising of Sirius (Sopdet) in the centuries around 2820 B.C.E. or, most interestingly, 2500 B.C.E. if the helical rising phenomenon is considered (Sirius needs to reach an angular height of at least $2^{\circ}$ in that case). The first author has defended the hypothesis that the helical rising of Sirius (Peret Sopdet) was not crucial for the creation of the civil calendar but that it would have soon become important as the harbinger of the real flooding, once Wepet Renpet had significantly departed from the arrival of the waters, due to the wandering nature of the calendar ${ }^{23}$. This early orientation to Peret Sopdet might indicate that this process could already have started in the Fourth Dynasty. Finally, Zawiyet el Mayitin (see Table 1 and Figure 4) offers a curious orientation to sunset at the winter solstice (declination of the centre of the sun disk near $-24^{\circ}$ during the reign of Snefru), one of the most conspicuous astronomical orientations of ancient Egyptian sacred structures in time and space, as demonstrated in Paper 4. Hence Naqada and El Mayitin also offer connections to time keeping and

21. Belmonte, 2003. The civil calendar was presumably in operation not later than 2640 B.C.E.

22. Several pyramids of the Old Kingdom have geometries that showed intriguing light and shadow effects at the time of the solstices (or equinoxes) that might have been used as time-markers, as shown, for example, in Belmonte / Zedda, 2007. See also Paper 3, Part II. Recent observations of winter solstice sunset at the NW corner of the Bent Pyramid as seen from the statue (valley) temple of Snefru at Dahshur abound on the same phenomenology.

23. See, Belmonte, 2003. 




Figure 5.Different celestial configurations of the "imperishable" asterism of Meskhetyu (the Plough or Big Dipper) and other circumpolar constellations as seen from the location of four MSPs, ca. 2570 B.C.E. Lower transit of Merak ( $\beta U M a)$, and hence of Meskhetyu, for Ghoneimiya (a) and Sinki (b); lower transit of Polaris ( $\alpha U M i)$, in the asterism of the Small Dipper (presumably the Small Adze), in the case of Zawiyet el Mayitin (c); and, finally, simultaneous meridian transit of Phecda $(\gamma U M a)$ and Megrez ( $\delta U M a)$, signalling almost duenorth in the case of Seila $(d)$.

the proposed questioning process of the civil calendar, supporting the result of Elephantine. Indirectly, these findings would also link our ideas to those of Krauss and the arrival of the the helical rising of Sirius.

The other group of four MSPs also offers a very suggestive alternative to the prosaic Nile orientations. Indeed, the N-S direction was determined in the four cases with a precision $\left(3^{1 / 2^{\circ}}, 1 \frac{1 / 4^{\circ}, 34^{3}}{}\right.$ and $\left.0^{\circ}\right)$ that can hardly be ascribed to chance. The axis of

El Ghoneimiya was orientated to a chain of hills located on the northern horizon. The lowest declination star of the asterism of the Plough (or Big Dipper, see Figure 5a), corresponding to the Egyptian constellation of Meskhety $u^{24}$, Merak, was slightly hidden by these hills at the time of Snefru (for coherency, we will centre all the following analysis on the date 2570 B.C.E.). Meskhetyu is mentioned in the Pyramid Texts (hereafter PT) as the "imperishable" group of stars par excellence, the Imperishable Stars being one of the various celestial destinies of the soul

24. For a recent review on the identification of ancient Egyptian constellations, see Lull / Belmonte, 2006. 
of the king after death ${ }^{25}$. Meskhetyu, normally represented as a bull's foreleg, was also identified as one of the celestial adzes used in the ubiquitous ceremony of the Opening of the Mouth, when the mummy of the deceased was brought back to life. The other adze might be identified with the Small Dipper (Ursa Minor) ${ }^{26}$.

It is a matter of fact that the area between El Ghoneimiya and El Kula was ca. 2570 B.C.E. the region of Egypt where Meskhetyu ceased to be circumpolar and the location and orientation of these MSPs, one cardinal and the other quarter-cardinal, might perhaps reflect this. This idea could be confirmed for the next pyramid of the group, Sinki. The authors are now arguing that (see, for example, Paper 4) the location of the earliest royal necropolis at Umm el Qab, in the desert area of Abydos and about $10 \mathrm{~km}$ to the north of Sin$\mathrm{ki}$, was related to the fact that Umm el Qab was the last spot in Egypt where Meskhetyu was circumpolar at the period of formation of the Egyptian state (ca. 3000 B.C.E.). However, another possibility is just the opposite, i.e. that Meskhetyu became important for the royal star eschatology, later stressed in the PT or in other funeral ceremonies, precisely because it was circumpolar at the royal necropolis. Whichever of the two alternatives is the true one, the location of Sinki close to the royal field and with an orientation so similar to although less marked than that of El Kula (Table 1 and Figure 5b), clearly includes it within the same line or reasoning.
The final MSP of the group is Seila. In Paper 2 we discussed the case of this fascinating monument and we still maintain the idea that it might have been the first pyramid (not necessarily the first monument) to be cardinally orientated through the simultaneous lower transit observation of two of the stars of Meskhetyu (Figure 5d), an idea that the first author was the first to propose for some of the larger pyramids $^{27}$, as well as highlighting the significance of their being constructed at a very peculiar latitude for solar illumination effects ${ }^{28}$. Once more the connection with Meskhetyu and the origins of the stellar afterlife justify our argument. In the light of these new discoveries, we would support the idea that precise N-S alignments should have been obtained through stellar observations, although there have been quite reasonable alternative proposals dealing with solar procedures ${ }^{29}$.

To finish our line of argument connecting MSPs with important aspects of ancient Egyptian astronomy and culture, we will return briefly to the three pyramids not belonging to the cardinal and quarter-cardinal group. El Mayitin was located in a very particular spot, where the lowest culmination of Polaris ( $\alpha \mathrm{UMi})$ was "tangential" to the horizon (Figure $5 \mathrm{c})^{30}$, and hence Ursa Minor, (the "Small Adze"), would cease to be circumpolar when travelling south $c a .2570$ B.C.E. The parallelism with the location of the pair GhoneimiyaEl Kula and the Plough (the "Big Adze", i.e. Meskhetyu), is indeed appealing. It is also worth mentioning that Sopdet, the star related

25. Krauss, 1997.

26. Actually, the oldest references, specially the PT, might refer to two blades that would have been attached to the head of the adzes. These blades were called sometimes sebawy (the two stars) in contemporary sources. Roth, 1993. See also, Paper 3, Part II.

27. Belmonte, 2001. In Paper 4, we have shown that this sort of orientation procedure could be originated in Upper Egypt, notably Hierakonpolis, in the pre-dynastic period. The idea of the simultaneous transit of stars as possible targets for ancient Egyptian pyramid orientations was resurrected by K. Spence in a most controversial paper: Spence, 2000.

28. Magdolen, 2000: 207-217. See also, Belmonte / Zedda, 2007.

29. As for example, in Isler, 1989.

30. As a general rule, stars are invisible until they reach an angular height close to their apparent magnitude. $\alpha$ UMi has a visual magnitude of 2.5 and would be invisible until it reaches $h \sim 2 \frac{1}{2}^{\circ}$. For a discussion on the extinction problem, see Schaefer, 1986. 
to Naqada, is the astronomical object most frequently mentioned by name in the $\mathrm{PT}^{31}$. Finally, it is important to stress that the stellar eschatology of the PT was partly conceived either simultaneously or once the civil calendar was already in operation since the 5 above the year (the "epagomenal" days, heralding Wepet Renpet in the Egyptian calendar) are mentioned there on one occasion. In summary, all seven MSPs (Elephantine is less clear) could be connected to a certain aspect of the Afterlife as later shaped in the PT written on the walls of the $5^{\text {th }}$ and $6^{\text {th }}$ Dynasty pyramids two centuries later.

\section{Challenging The Enigma?}

Consequently, our study relating astronomy and landscape has shown that MSPs were built at certain geographical locations and with orientations that would be strongly correlated with two important aspects of ancient Egyptian culture that were being developed at the time of their construction: the civil calendar and the stellar eschatology. Our proposal would agree with the sacred character of these monuments and their temporal ascription (to the early reign of Snefru, who ought to be credited with having started the construction of at least 12 pyramids) as proposed by Ćwiek ${ }^{32}$ and might also agree with certain geographical properties, as discovered by Krauss, at least for MSPs (1), (3), (4) and (5), and especially for the pyramids of Elephantine and Naqada, [16] whose orientations could be connected to spe- cial events in the Egyptian time-keeping system such as Wepet Renpet and Peret Sopdet, respectively, and presumably with the arrival of the Flooding.

Particular celestial configurations such as Meskhetyu, and perhaps the "Small Adze", would define the sites where four of the MSPs were erected, as well as their orientation. The observation of yet another configuration would have offered at Seila the first sacred Egyptian building ever accurately orientated to the cardinal directions (probably with the nearby gigantic step pyramid of Meidum). There is a clear association with the idea of (step) pyramids being stairs to the celestial realm and especially to the area surrounding the Pole where the "imperishable" stars par excellence, those of Meskhetyu, were turning endlessly.

Summarizing, our archaeoastronomical work permits us the following conclusions: (i) MSPs were presumably built by Snefru ( $c a$. 2570 B.C.E.), and (ii) they would form two interrelated groups of monuments with a strong symbolic character connected with the preliminary stages and consolidation of two master creations of early dynastic Egypt, the civil calendar and the stellar Afterlife. If we are right, the minor step pyramids should no longer be seen as an unsolved enigma but rather as significant links in a chain of monuments built for centuries in ancient Egypt for the greater glory of their kings, both in this and the afterlife, and hence for preserving the concept of $M a$ 'at in ancient Egyptian society.

31. Maravelia, 2006, Table III.2. For the importance of Sirius, see also Krauss, 1997.

32. Ćwiek, 1998. 


\section{BIBLIOGRAPHY}

VON BECKERATH, J.

1997 Chronologie des pharaonischen Ägypten. Mainz.

Belmonte, J. A.

2001 "On the orientation of the Old Kingdom pyramids", Archaeoastronomy 26: S1-S20.

2003 "Some open questions on the Egyptian calendar: an astronomer's view", $T d E$ 2: 7-56.

2006 "Astronomy on the horizon and dating, a tool for ancient Egyptian chronology?", in Hornung / Krauss / Warburton (eds.): 380-5.

Belmonte, J. A.; Shaltout, M.

2006 "On the orientation of ancient Egyptian temples: (2) new experiments at the oases of the Western Desert", Journal for the History of Astronomy XXXVII: 173-92.

Belmonte, J. A.; Shaltout, M.; Fekri, M. in press "On the orientation of ancient Egyptian temples: (4) epilogue in Serabit el Khadim and overview", Journal for the History of Astronomy XXXIX (2008)/ 2.

Belmonte, J. A.; Zedda, M.

2007 "Light and shadows on the pyramids", in M. Zedda and J. A. Belmonte (eds.): Light and shadows in cultural astronomy. Proceedings of the SEAC $13^{\text {th }}$ Meeting held in Isili (Italy) in 2005. Cagliari: 188-196.

ĆWIEK, A.

1998 "Date and Function of the so-called Minor Step Pyramids", GM CLXII: 39-52.

Denon, D. V.

1802 Voyage en Basse et Haute Égypte. Paris.

Dodson, A.

2003 "The Multiple Pyramids of Snefru", in B. Manley (ed.): The Seventy Great Mysteries of Ancient Egypt. London: 57-60.

Dodson, A.; Hilton, D.

2004 The complete royal families of ancient Egypt. London.

Dreyer, G.; KaISER, W.

1980 "Zu den kleinen Stufenpyramiden Oberund Mittelägyptens", MDAIK XXXVI: 43-59, Tafeln 68-77.

Dreyer, G.; Swelim, N.

1982 "Die kleine Stufenpyramide von Abydos-Süd (Sinki)", MDAIK XXXVIII: 84-95, Tafeln 11-14.

Hornung, E.; KRAUSS, R.; WarbuRTOn, D. A. (EDS.)

2006 Ancient Egyptian Chronology. (Handbuch der Orientalistik, LXXXIII). Berlin.

ISLER, $\mathrm{M}$.

1989 "An ancient method of finding and extending direction", JARCE XXVI: 191-206.

Kaiser, W.; Dreyer, G.; Grossmann, P.; Mayer, W.; Seidlmayer, S.

1980 "Stadt und Tempel von Elephantine xxx", MDAIK XXXVI: 276-80.

KRAUSS, R.

1997 Astronomische Konzepte und Jenseitsvorstellungen in den Pyramidentexten. (ÄA 59). Wiesbaden.

LEHNER, M.

1997 The Complete Pyramids. London.

Lull, J.; Belmonte, J. A.

2006 "A firmament above Thebes: uncovering the constellations of ancient Egyptians", Journal for the History of Astronomy XXXVII: 373-92. 
Magdolen, D.

2000 "The solar origin of the sacred triangle in ancient Egypt", SAK XXVIII: 207-217.

Maravelia, A. A.

2006 Les Astres dans les Textes Religieux en Égypte Antique et dans les Hymnes Orphiques. (BAR Int. Ser., 1527). Oxford.

Rотн, A. M.

1993 "Fingers, stars and the opening of the mouth: the nature and function of the ntrwi-blades", JEA LXXIX: 57-79.

SCHAEFER, B. E.

1986 "Atmospheric extinction effects on stellar alignments", Archaeoastronomy 10: S32-S42.

Shaltout, M.; Belmonte, J. A.

2005 "On the orientation of ancient Egyptian temples: (1) Upper Egypt and Lower Nubia", Journal for the History of Astronomy XXXVI, 273-98.
Shaltout, M.; Belmonte, J. A.; Fekri, M.

2007 "On the orientation of ancient Egyptian temples: (3) key points in Lower Egypt and Siwa Oasis (Part I)", Journal for the History of Astronomy XXXVIII / 2: 141-60.

2007 "On the orientation of ancient Egyptian temples: (3) key points in Lower Egypt and Siwa Oasis (Part II)", Journal for the History of Astronomy XXXVIII / 4: 413-442.

SHAW, I. (ED.)

2000 The Oxford History of Ancient Egypt. Oxford.

SPENCE, K.

2000 "Ancient Egyptian chronology and the astronomical orientation of pyramids", Nature 408: 320-4.

Swelim, N.

1987 "The Pyramid of Seila Locally Called "El Qalah". The season of 1987", Newsletter of the BYU Expedition in the Fayum. Egypt, March issue. 


\section{Juan Antonio Belmonte}

Instituto de Astrofísica de Canarias

Vía Láctea $\mathrm{S} / \mathrm{N}$

38200 La Laguna, Tenerife - Islas Canarias

España

$$
\text { jba@iac.es }
$$

\section{Marcelo Campagno}

Instituto Multidisciplinario de Historia y Ciencias Humanas

Departamento de Egiptología

Saavedra $15,5^{\circ}$ piso

C1083ACA Buenos Aires

Argentina

mcampagno@fibertel.com.ar

\section{Lucía Elena Díaz-Iglesias Llanos}

Dpto. de Prehistoria, Antropología e Historia Antigua

Facultad de Geografía e Historia - Campus de Guajara

38071 Universidad de La Laguna

Tenerife - Islas Canarias

España

luch68@hotmail.com

\section{Magdi Fekri}

Faculty of Tourism

Minufiya University

El-Sadat City

Egypt

per-ankh@hotmail.com

\section{Cristina Pino Fernández}

cristinapino@telefonica.net 


\section{Mosalam Shaltout}

Helwan Observatory

Helwan, Cairo

Egypt

mosalamshaltout@hotmail.com

\section{Eric P. Uphill}

Institute of Archaeology

University of London

31-34 Gordon Square

London WC1H OPY

United Kingdom

\section{Marie-Paule Vanlathem}

Association Égyptologique Reine Élisabeth Musées Royaux d'Art et d'Histoire

Parc du Cinquantenaire 10

B-1000 Bruxelles

Belgique

mariepaule.vanlathem@belgacom.net 


\section{Trabajos de Egiptología}

\section{Papers on Ancient Egypt}

P

Número 4 2005 


\title{
Consejo Editorial
}

\author{
Miguel Á. Molinero Polo \\ Universidad de La Laguna \\ Antonio Pérez Largacha \\ Universidad de Castilla-La Mancha \\ José-R. Pérez-Accino \\ Birkbeck, Universidad de Londres \\ Covadonga Sevilla Cueva \\ Universidad Autónoma de Madrid
}

\section{Comité Científico}

Josep Cervelló i Autuori

Aula Aegyptiaca, Barcelona

Ma José López Grande

Universidad Autónoma de Madrid

Josep Padró i Parcerisa

Universitat de Barcelona

$\mathrm{M}^{\mathrm{a}}$ Carmen Pérez Die

Museo Arqueológico Nacional, Madrid

Ester Pons Mellado

Museo Arqueológico Nacional, Madrid

José M. Serrano Delgado

Universidad de Sevilla

\section{Colaboradores Editoriales}

Linda Steynor

English editorial assistant

Hervé Mouriacoux

Assistant editoriale pour langue française 
Juan Antonio Belmonte, Mosalam Shaltout, Magdi Fekri

Astronomy and landscape in Ancient Egypt:

Challenging the enigma of the minor step pyramids

\section{Marcelo Campagno}

Two observations on the tales of The contendings of Horus and Seth and Truth and Falsehood

\section{Lucía Elena Díaz-Iglesias Llanos}

Commentary on Heracleopolis Magna from the theological perspective (I):

The image of the local lakes in the vignette of chapter 17 of the Book of the Dead

Cristina Pino Fernández

Prince Ahmose Sapair again

Eric P. Uphill

Irrigation basins and cultivated land under the Twelfth Dynasty

\section{Marie-Paule Vanlathem}

Cléopâtre dans le miroir de la peinture du XIXe siècle 
Trabajos de Egiptología está producida por Isfet. Egiptología e Historia.

c/ Blanco $1,2^{\circ}$

38400 Puerto de la Cruz

Tenerife - Islas Canarias

España

Maquetación: Ignacio Cases

(C) Autores de los artículos aparecidos

y Consejo Editorial de Trabajos de Egiptología - Papers on ancient Egypt

Depósito legal:

ISSN 1695-4750

Impresión: 